\title{
The mediating effect of environmental and ethical behaviour on supply chain partnership decisions and management appreciation of supplier partnership risks
}

\author{
David Gallear ${ }^{\mathrm{a}}$, Abby Ghobadian $^{\mathrm{b}}$ and Qile $\mathrm{He}^{\mathrm{c}}$ \\ ${ }^{a}$ Brunel Business School, Brunel University, Uxbridge, UK \\ ${ }^{\mathrm{b}}$ Henley Business School, University of Reading, Henley-on-Thames, UK \\ ${ }^{c}$ Department of Management and Business Systems, University of Bedfordshire Business \\ School, Luton, UK
}

\begin{abstract}
Green supply chain management and environmental and ethical behaviour (EEB), a major component of corporate responsibility (CR), are rapidly developing fields in research and practice. The influence and effect of EEB at the functional level, however, is under-researched. Similarly, the management of risk in the supply chain has become a practical concern for many firms. It is important that managers have a good understanding of the risks associated with supplier partnerships. This paper examines the effect of firms' investment in EEB as part of corporate social responsibility in mediating the relationship between supply chain partnership and management appreciation of the risk of partnering. We hypothesise that simply entering into a supply chain partnership does not facilitate an appreciation of the risk of partnering and may even hamper such awareness. However, such an appreciation of the risk is facilitated through CR's environmental and stakeholder management ethos. The study contributes further by separating risk into distinct relational and performance components. The results of a firm-level survey confirm the mediation effect, highlighting the value to supply chain strategy and design of investing in EEB on three fronts: building internal awareness, monitoring and sharing best practice.
\end{abstract}

Keywords: environmental and ethical behaviour; corporate responsibility; supplier partnerships; relational risk; performance risk; mediation. 


\section{Introduction}

In this paper we examine the relationship between supply chain partnership and two critical organisational risks - namely, relational and performance risks - and the mediating role of environmental and ethical behaviour (EEB). Corporate responsibility (CR) is an umbrella concept encompassing policies and practices that direct firms' relationships with a broad range of stakeholders and the environment (Ghobadian et al., 2007). Managers are increasingly called to make choices between keeping a transactional relationship with suppliers or adopting a partnership approach, and whether to adopt CR with a strong EEB component. In making these decisions managers need decision support that, for example, enables them to determine whether supply partnerships' impact on key risks is or is not independent of CR that encompasses clear EEB practices. Investigating these questions is important from an academic and a practical point of view because supply chain partnership is considered a cornerstone of strategic supply chain management, CR and the EEB practices it encompasses are growing in importance, and risk is a critical factor in supply chain management. Furthermore, as far as we have been able to ascertain the mediating role of EEB in relation to supply chain partnership and risk has not been studied empirically.

Developing partnership with suppliers is considered an important aspect of supply chain design and a driver of competitive advantage, and the concept has broad appeal (Mentzer et al., 2000; Gallear et al., 2012). Partnerships exist in order to create value for each of the parties involved, in essence meaning that one party exchanges some 'value package' that the other side finds worthwhile to reciprocate in the form of some other 'value package' (Lemke et al., 2003). The question: 'What makes a partnership more effective?' has been the subject of much research effort (e.g. Ren et al., 2010; Maheshwari et al., 2006), but the potential role of EEB in this respect has not been examined empirically in any depth. Hence, managers making decisions with regard to introducing or maintaining supply chain partnership are not clear whether or not introducing EEB in parallel is a help or a hindrance to the beneficial impacts of supply chain partnership.

Improving firms' environmental and ethical performance is among executives' top concerns (UNSRID, 2002; Cruz, 2009). The literature examining green manufacturing, green supply chains and more broadly corporate responsibility is developing rapidly (Kumar et al., 2012; Holt and Ghobadian, 2009; Rao and Holt, 2005; Waddock, 2004). Corporate responsibility, 'the strategies and operating practices that a firm deploys in its efforts to deal with and create relationships with its numerous stakeholders' (Surroca et al., 2010), has emerged and taken root since the mid to late 1990s (Waddock, 2004). ). Corporate responsibility encompasses policies and practices that direct firms' relationships with a broad range of stakeholders, which includes the physical environment because 
all stakeholders have a shared interest in the natural environment (Waddock, 2008). We contend that CR embraces environmental policies of the firm including its effort to 'green' the elements of the supply chain (Cruz and Matsypura, 2009). Growing evidence suggests that shrewd firms investing in CR are likely to have a competitive advantage over those that do not (Paine 2003; Heal, 2008; Shavit and Adam, 2011; Lu et al., 2013). Shavit and Adam (2011) go as far as to argue that for prospective investors the attractiveness of a firm is contingent on its (visible) commitment to CR and that it 'seems that the choice to invest in CR is to some extent no longer an open option', instead 'the focus is [now] on the extent to which a firm will make the choice of allocating its resources towards CR'. Hart (1995) argued that competitive advantage is rooted in capabilities that facilitate environmentally sustainable economic activity. To this end, in this study we are concerned with CR practices with a focus on environmentally friendly and ethical behaviour of supply chains.

Similarly, the management of risk at an operational level has become a practical concern for many firms across manufacturing and service sectors alike (Schwartz and Gibb, 1999; Lewis, 2003). Risk is now a key strategic management focus (Arnold et al., 2010). Cruz (2013) notes that the need to incorporate risk in analysis and decision-making within supply chains is indisputable (Zsidisin, 2003; Johnson, 2001). This is not least because of risk's strong correlation with the increasingly prominent concept of supply chain vulnerability (Christopher and Peck, 2004; Colicchia and Strozzi, 2012). Jüttner et al. argued in 2003 that despite firms' awareness for some considerable time of the need for risk management in general, and the appearance of a wide and diverse body of accompanying literature in varied fields such as strategic management and economics, there were very few systematic and structured approaches to conceptualising supply chain risks. Nearly a decade later, Arnold et al. (2010) noted that relatively little is still known about the processes used to minimise risks for supply chain members. This led them to propose that substantial research is needed in order to better understand the various influences on risk in supply chain relationships. The question therefore arises: 'What can cultivate within firms a better appreciation of these risks?' Because risk is inevitable when stakeholders enter into transactions with each other, but firms have too often been found to have failed to deal with risks (Hendricks and Singhal, 2005; Khan and Burnes, 2007), it is important that research is undertaken to understand which factors facilitate a deeper appreciation of the risks associated with stakeholder relationships, notably supply partnerships.

In this paper we examine the mediating role of firms' EEB attitudes, policies and practices (under the umbrella of $\mathrm{CR}$ ) between supply chain partnership (independent variable) and appreciation of relational and performance risks (dependent variables). A great deal of research has considered CR and by implication EEB at the organisational level, including its interaction with corporate and/or 
business strategy (Laplume et al., 2008). Furthermore, at the corporate level, it is widely acknowledged that $\mathrm{CR}$, and by implication its EEB elements, helps firms to reduce their exposure to risk (Salama et al., 2011; Jo and Na, 2012). Salama et al. (2011), using the largest dataset assembled (at that time) of environmental and community responsibility rankings for all rated UK companies, found that developing a reputation for good environmental and social performance also amounts to good risk management.

Strategy at a functional level generally focuses on the maximisation of resource productivity within or through the function in question, not least within the operations and marketing functions of a firm (Hofer and Schendel, 1978). However, the effect of CR and EEB at the functional level of the firm (with the possible exception of marketing/branding, e.g. Lacey et al., 2010; Vancheswaran and Gautam, 2011) and particularly in conjunction with risk, has seldom been considered or tested. In this paper we address this gap in the literature. Our study is located within what is now recognised as a core functional strategy of the firm, namely the purchasing and supply management function (Virolainen, 1998; Baier et al., 2008), with a specific focus on supply chain partnership and the role of EEB in mediating the relationship between partnership and risk.

In this study we take our lead from Waddock (2004), by viewing CR as a portfolio of actions undertaken by an organisation to develop or enhance its legitimacy or to bolster its competiveness. These policies include environmental and ethical policies of the firm often referred to as 'greening of the supply chain'. Many of the measures we deploy in this study firmly fall within the greening area (see Appendix 1). Trust plays a key role in the longevity and success of supply chain partnerships (He et al., 2011; Wu et al., 2012). Despite the fact that trust is considered critical, there are very few studies that examine how trust can be developed and offer a decision support mechanism to managers. The rationale for introducing supply chain EEB in the context of CR leads us to the institutional theory. Institutional theory argues that organisations develop structural rules and procedures to enhance legitimacy with external parties (DiMaggio and Powell, 1983; Suchman, 1995; Meyer and Rowan, 1983). Therefore according to institutional theory, supply chain EEB can be viewed as actions undertaken by an organisation to enhance its legitimacy among its suppliers. Legitimacy and trust are unidirectional and highly correlated (Lagenspetz, 1992). Trust plays an important role in collaborative type strategies such as supply chain partnership (Mesquita, 2007; Krishnan et al., 2006) and it is popularly defined as 'confident positive expectations regarding another's conduct' (Lewicki et al., 1998, p. 439). There are two main conditions that must exist to give rise to trust - risk and interdependence (Rousseau et al., 1998). Hillenbrand, et al. (2013) showed that self-related CR experiences significantly impact on belief and trust towards an 
organisation. Taking these arguments together, we theorise that EEB mediates the relationship between supply chain partnership and appreciation of two types of risk. Suppliers participating in supply chain partnership with firms practicing EEB as part of their CR programme will experience the buyers' EEB practices, resulting in greater legitimacy and growing trust for the buyer from the supplier. Risk is the possibility of loss, as subjectively determined by the decision maker, and it can be better assessed and guarded against with the availability of greater and better information (Chiles and McMackin, 1996). We theorise that a greater trust for the buyer from the supplier, derived from EEB practices, will lead to a more open relationship and greater and more reliable flow of information from buyer to supplier enabling buying firm managers to develop a better appreciation of relational and performance risk in relation to their supply chain supply partner. In other words, we theorise that the benefits of partnership are enhanced because buyers' EEB increase its legitimacy among its supply chain partners, resulting in a better and more reliable flow of information, which in turn enhances appreciation of the two types of risk. Hence, 'supply chain partnership' is more effective in organisations that practice 'supply chain EEB' compared to organisations that solely practice the former.

It is therefore the contention of this study that increased levels of EEB internal awareness, EEB monitoring and EEB best practice sharing will result in greater levels of management appreciation (i.e. awareness and recognition) of the risk of partnership. Accordingly, in this study we were specifically concerned with relational and performance risk. Relational risk is important because partnership is about relationships, and if relationships break down the partnership is likely to break down. If the firm has a good appreciation of the relational risks they can mitigate against them. Performance risk is important because ultimately firms enter partnerships to improve their performance. The main proposition of this paper is that EEB mediates the relationship between a partnership orientation and management's appreciation of relational and performance risks. We hypothesise that there is no direct relationship between partnership orientation and management's appreciation of relational risk and performance risk. Instead, that providing that the firm has a proclivity towards a partnering ethos, management's appreciation of the risk of partnership will be facilitated and greatly enhanced through the implementation of EEB attitudes, policies and practices. In doing so, this paper contributes to the increasingly significant area of research concerned with green supply chain design and operations. Our research model (Figure 1) depicts the proposed mediating relationship.

[Take in Figure 1. Research Model about here.] 
Through these efforts, we attempt to enrich the understanding of how firms' EEB supports or otherwise the development of more risk responsive and better risk managed, and therefore more sustainable, partnerships in the supply chain.

This paper is organised as follows. Section 2 presents our research framework and the research hypotheses based on examination of the extant literature. In Section 3 we describe the methodology of the study. Section 4 presents our findings. Section 5 concludes with discussion of the findings and their managerial implications, and with recommendations of directions for future research.

\section{Conceptual development}

In this study we were particularly interested in supply chain partnerships for two, arguably interconnected, reasons. Firstly, because of their prevalence (Trent, 2005) and, secondly, because of their features, which distinguish them from other types of inter-organisational relationships. The latter undoubtedly explains the former. Unlike other types of inter-organisational relationships such as strategic alliances or joint ventures, supply chain partnerships are much more loosely organised in terms of contractual agreements (Wilson, 1995; Frankel et al., 1996; Lambert et al., 1996b). To this end, it has been noted that the strongest partnerships often have the shortest and least specific agreements or even none at all (Lambert et al., 1996a). Partnerships seldom have any direct equity investment (Stuart, 1997) or any legal structures defining their boundaries (Wilson, 1995). Furthermore, the lack of contractual agreements means that, similarly, the firms involved rarely have specific (written) tangible or quantifiable requirements in terms of the benefits and returns expected (Wilson, 1995; Li et al., 2006). Unlike other types of inter-organisational relationships in manufacturing supply chains such as strategic/R\&D alliances or licensing agreements, which involve horizontal complementarities and cooperation (Pekar and Allio, 1994), with partnerships the cooperation tends mostly to be across vertical interfaces (Maloni and Benton, 1997), and hence its common positioning as a type of buyer-supplier relationship.

Many different definitions of risk can be found in the literature (e.g. Mitchell, 1995). Nevertheless, there is generally broad agreement as Lewis (2003) notes that in the context of the operations management field, 'risk is the potential for realising unwanted negative consequences from causal events' (Rowe, 1977, p. 23). This popular definition highlights the two dimensions characterising risk, namely the impact and the likelihood of occurrence (Faisal et al. 2006; Colicchia and Strozzi, 2012). A review of the operations management and risk management literature indicates that the subject is still relatively under-researched (Lewis, 2003). 
Corporate responsibility is described by Waddock (2004) as 'the degree of (ir)responsibility manifested in a company's strategies and operating practices as they impact stakeholders and the natural environment day to day'. We adopted Waddock's (2004) definition for this study as it explicitly recognises that the natural environment forms part of the organisation's CR activities. Furthermore, a focus on strategies and operating practices offers greater opportunity to operationalise the constructs objectively by identifying actual CR-related routines including those that are relevant to green supply chain management. Our examination of the literature identified three key components of CR germane to EEB: developing EEB internal awareness, monitoring EEB performance and sharing EEB best practice. It was important that we operationalised EEB through tangible practices/activities. Accordingly, the salience of these components is also supported by environmental/ethical responsibility development processes proposed in the literature (Carlisle and Faulkner, 2004; Vachon and Klassen 2006). Vachon and Klassen (2006) identified monitoring (an internalisation practice) and collaboration/sharing (an externalisation practice) as two sets of environmental practices/activities supporting greater integration, during their work examining how green practices can be extended from firms to their supply chain partners. Carlisle and Faulkner (2004) identified a process comprising structural changes coupled with increasingly effective practices to promote responsible behaviour. The process starts with developing and promoting awareness, leading to initial implementation that includes developing quantifiable measures, and consolidates with mainstreaming (e.g. collaboration/effective practices). Identification of the three EEB study variables thus leads us to present our study hypotheses.

\subsection{Hypotheses}

\subsubsection{Supply chain partnership and environmental and ethical behaviour}

The literature supports the proposition that firms that are inclined to see the value in a partnership approach with their main suppliers and develop such partnerships are, by virtue of their externally facing mind-set, also the type of firm that is more inclined to proactively embrace EEBs (Cheung et al., 2009).

Internal awareness refers to employees' familiarity with the firm's EEB values and orientation (Hopkins, 2005). It can be created through various mechanisms ranging from the appointment of a champion to oversee EEB policy (Carlisle and Faulkner, 2004), publishing and disseminating green (environmental and ethical) reports (Carlisle and Faulkner, 2004), and developing and communicating clear policy statements on acceptable practices (Park-Poaps and Rees, 2010), all of 
which can be linked to a mission statement and can be cascaded through internal training (Madsen and Ulhoi, 2001). Thus:

H1a: A greater partnership orientation has a positive impact on EEB internal awareness.

Monitoring in the EEB context is associated both with compliance and with pre-emptive /preventative planning. It involves the firm monitoring their existing behaviour (and indeed that of salient stakeholders) (Mitchell et al., 1997) in order to ascertain, and ultimately to help ensure, that the behaviour is acceptable and meets or exceeds what is expected (Lebas, 1995). Waddock et al. (2002) emphasise that the literature strongly agrees that monitoring is crucial to the enhancement of responsible behaviour in organisations. Thus:

H1b: A greater partnership orientation has a positive impact on EEB monitoring.

The sharing of know-how is an increasingly important practice in supply chain management (Akacum and Dale, 1995), not least the sharing of best practice, which goes beyond knowledge exchange geared for general efficiency improvement and that is concerned with the development of joint, mutually beneficial capabilities. Environmental and ethical behaviour best practices that promote two-way exchange and the problem solving ethos that underpins risk management include the engagement of suppliers as equal partners in joint training programmes (Carr et al., 2008), supplier participation in ISO 14000 Environmental Management Systems Standards accreditation, and the inclusion of environmental and ethical standards in collaborative activities (Zineldin and Bredenlow, 2003). Thus:

H1c: A greater partnership orientation has a positive impact on EEB sharing best practice.

\subsubsection{Environmental and ethical behaviour and appreciation of risk}

At the corporate level, the relationship between $C R$ and risk reduction is widely acknowledged. Alongside enhancing their reputation (Fombrun, 2005), generating customer loyalty (Bhattacharya and Sen, 2001) and avoiding legal sanction (Parker, 2002) for example, firms engage in CR activities as a way of managing their risk (Husted, 2005; Cruz, 2009). Cruz's (2013) study found that CR activities can potentially be used to mitigate risk within global supply chains. This view is shared by Welford and Frost (2006) who argue that one of the benefits of CR is risk reduction. Feldman et al. (1997) found that adopting a more environmentally proactive attitude has a substantial positive impact on the firm's perceived riskiness to investors and consequently its value in the marketplace, in addition to direct environmental benefits (Cruz, 2009). It is claimed, as Cruz (2009) further notes, that firms who practice proactive $\mathrm{CR}$ and that engage in environmental assessment and stakeholder 
management (Bowman, 1980), are likely to anticipate and reduce potential sources of business risk, notably environmental damage, likely governmental regulation or adverse labour issues (Orlitzky and Benjamin, 2001). However, these studies implicitly draw on transactional theory and do not explicitly explain how $x$ results in $y$. In this study we open the black box and offer a theoretically based reasoning as to why supply chain partnership and EEB result in better appreciation of risk.

According to Jia and Rutherford (2010), supply chain risk management aims to avoid or constrain supply chain vulnerability by identifying potential sources of risk and implementing appropriate prevention or mitigation actions. In the context of inter-firm relationships Das and Teng (2001) made a clear distinction between what they call relational risk, and what they call performance risk. According to Delerue (2004), relational risk is generally defined as 'the probability and consequence of not having satisfactory cooperation (Das and Teng, 1996) or as the probability and consequence of opportunistic behaviour by the partner (Nooteboom et al., 1997)'. This led Jia and Rutherford (2010) to propose a working definition of relational risk, located in the supply chain context, namely 'the risk to the supply chain of either party in a buyer-supplier relationship not fully committing to joint efforts due to either problems associated with cooperation or problems associated with opportunistic behaviour'. According to Das and Teng (2001), performance risk refers to those factors that may jeopardise the success of a relationship, even when the partners cooperate fully, in other words, where strategic objectives are not achieved for reasons other than collaboration and/or cooperation. Consequently, what Das and Teng (2001) term performance risk is present in all strategic manoeuvres.

Taking our lead from the institutional theory, our theoretical propositions suggest that suppliers participating in supply chain partnership with firms practising EEB in the context of their CR programme will experience the buyers' EEB practices resulting in greater legitimacy and growing trust for the buyer from the supplier. The literature supports this proposition. For example, firms that take a proactive approach to CR are, by virtue of their efforts to deal with their stakeholders and the natural environment (Waddock, 2004) through awareness building, monitoring and best practice sharing, more inclined to have a deeper appreciation of the risks associated with stakeholder relationships (Cruz, 2009, 2013), including supply partnerships. As alluded to previously, this is very important because controlling or mitigating such risks is critical in collaborative partnerships that have significant potential for benefits such as productivity and knowledge gains (Aron et al., 2005; Arnold et al., 2010).

Relational risk encompasses risks associated with the behaviour of partners. Relational risk therefore includes, for example, the over-estimating of the benefits of the partnership whilst ignoring the 
potential shortcomings (Maloni and Benton, 1997, Leavy, 1994), or imbalances with resources within the partnership (Katner, 1989). Thus:

H2a: The greater the internal awareness of EEB values and outcomes, the better is management appreciation of the relational risks (RR) associated with partnering.

H3a: The greater the monitoring of EEB performance, the better is management's appreciation of the relational risks (RR) associated with partnering.

H4a: The greater the sharing of EEB best practices, the better is management's appreciation of the relational risks (RR) associated with partnering.

Partnership performance risk relates to performance outcome risks, and includes for example, loss of competitiveness through the partnership, over-reliance on a partner, which subsequently fails to meet expectations (MacBeth and Ferguson, 1994), or the risk of disruptions in supply (Wakolbinger and Cruz, 2011). Thus:

H2b: The greater the internal awareness of EEB values and outcomes, the better is management's appreciation of the performance risks (PR) associated with partnering.

H3b: The greater the monitoring of EEB performance, the better is management's appreciation of the performance risks (PR) associated with partnering.

$\mathbf{H} \mathbf{4 b}$ : The greater the sharing of EEB best practices, the better is management's appreciation of the performance risks (PR) associated with partnering.

\subsubsection{Mediating effect of environmental and ethical behaviour on risk}

As mentioned previously, we propose a model in which EEBs are mediator variables between partnership orientation and management's appreciation of the risk associated with partnering. In other words, we hypothesise that while an inclination for partnering orientation is not sufficient in itself for helping to ensure management's appreciation of the risks of partnering, it is a good predictor of the firm's propensity to embrace EEB, and when a firm does proactively engage with EEB, its management's appreciation of the risk of partnership improves. Put another way, investing in a partnering approach improves EEB that in turn leads to a better appreciation of the risks associated with partnering; however, there is no direct relationship between partnership orientation and management's appreciation of relation risk and performance risk. This leads to our final two hypotheses: 
H5a: Environmental and ethical behaviours (EEBs) mediate the effect of partnership orientation on management appreciation of the relational risks (RR) associated with partnering.

H5b: Environmental and ethical behaviours (EEBs) mediate the effect of partnership orientation on management appreciation of the performance risks (PR) associated with partnering.

\section{Research methods}

We followed Dillman's (2000) tailored design method for developing and administering a questionnaire survey instrument to test the study hypotheses. Dillman's (2000) guidance helped us to ensure a close fit between the constructs, research context and the target population and to maximise the response rate.

The cross-sectional nature of our study, in which data was obtained from a large sample of firms, was a deliberate and important feature in adding to the extant knowledge as it allowed the systematic testing of the proposed mediation effect. The target respondents for the study were senior managers and directors in supply management roles or with supply management responsibility within their firms, operating in the supply chains of various industry sectors including chemical, oil, pharmaceutical products, fast-moving consumer goods, food and grocery products, automotive, and computer and IT hardware. Consistent with other large sample studies (Taylor, 2005) we adopted a single-informant approach (Phillips, 1981). The target sample was determined with help from the Chartered Institute of Logistics and Transport in the UK. Only those respondents considered capable of responding to the survey instrument were selected based on a careful analysis of their practitioner database. This process of scrutiny used the following criteria to ensure that only senior practitioners directly employed in designated supply management roles were selected: (1) the informant should hold a senior position with a job title specialised in supply chain management, logistics, purchasing, procurement, or other related area, or should hold a top-level senior position with integrating oversight across the key functions, such as job title CEO or managing director; and (2) complete specific individual contact details for the informant should be available. To maximise the likelihood that these carefully selected informants received and responded to the survey in person, we addressed the questionnaires together with a brief covering letter to the individual target informants, using their specific contact details that we had obtained (Vaus, 2004). These measures were taken to improve the quality of the responses and reduce the possibility of erroneous recall or respondent bias that can occur when a single informant data collection strategy is used (Fynes et al., 2005, Kumar et al., 1993). To improve the response rate we undertook a repeat mailing of the questionnaire (Dillman, 2000), and stimulated completion of the instrument by ensuring we 
subsequently provided a timely summary of the study findings to each participant following the closing of the survey and data analysis.

\subsection{Measures}

A two-stage process was used to develop the study measures for relational and performance risk and supply chain partnerships: an in-depth review of the associated and respective literatures, followed by pilot testing with industry practitioners.

We measured relational risk and performance risk with seven and three measures respectively, drawn from an extensive review of the literature. These two scales were closely informed by Delerue (2004) and Das and Teng (2001). Supply chain partnership was measured with five items after surveying the literature for a set of measures that could be used to indicate the presence of the partnership type relationship. A set of five were derived based closely on those presented by McDonald (1999) which were checked for construct validity by juxtaposing them against other salient contributions, for example Lambert et al. (1996b) and Mohr and Spekman (1994).

Having searched the literature for established measures of CR EEBs in the supply chain relationship context, we employed an alternative strategy for developing the items comprising this construct. While providing guidance, we found that the literature lacked the depth and consensus to provide an existing scale that was suitable. We were therefore guided by input from expert practitioners in developing our measures for EEB internal awareness, monitoring EEB performance and sharing EEB best practice. Starting with the supply chain EEB/CR framework proposed by Hughes et al. (1999) we consulted a panel of practitioners comprising senior managers with many years' experience working in senior supply management positions. Minor adjustments were made based on their feedback, enabling us to confirm the validity of the proposed measures as key practices and/or policies underpinning EEB in the domain of supply chain management. We therefore used four items to measure practices and policies promoting EEB internal awareness, two items to measure firms' monitoring of EEB performance, and four items to measure the sharing of EEB best practices.

The research instrument was also pilot tested to check its suitability and appropriateness for the target population, enabling us to have confidence in its content validity. The final instrument was administered as a postal questionnaire with a prepaid self-return envelope provided. After a followup mailing, 159 completed responses were received. Following screening of the returns for any respondents not meeting our aforementioned informant selection threshold, the administration of the research instrument had returned usable responses from 156 organisations, a response rate of $16 \%$ commensurate with that which is typical for surveys of senior managers (Li et al., 2006). 
Before data were entered into the subsequent analysis, multivariate normality of the data was examined (Kline, 2011). A test of skewness and kurtosis was performed using PRELIS software (Joreskog and Sorbom, 2004). We found that most variables have skewness or kurtosis within the range of -1 to +1 . Moreover, the insignificant $z$-statistics of most skewness and kurtosis indicators suggested that a violation of normality assumption was not a major concern (Hair et al., 2010; Schumacker and Lomax, 2004). This confirms the appropriateness of the data for multivariate modelling and the use of maximum likelihood (ML) as the estimation method in the subsequent structural equation modelling (SEM) analysis. The covariance matrix of original items is reported in Appendix 2. We also compared the data of early and late respondents for each study variable (Armstrong and Overton, 1977) using a multivariate t-test to check for the absence/presence of nonrespondent bias. The test confirmed that non-respondent bias was not an issue with the survey data.

\subsection{Validity and reliability}

To evaluate the validity and reliability of the survey instrument confirmatory factor analysis (CFA) was conducted (Hair et al., 2010) using LISREL 8.70 (Joreskog and Sorbom, 2004). All original survey items were entered into the measurement model according to their corresponding latent construct. The initial CFA results suggested that not all the standardised factor loadings were above the satisfactory threshold of 0.60 (Wallace et al., 2004). Therefore items with low factor loadings were evaluated based on the understanding of the meanings of the constructs and the underlying theory. Items with loadings of $<0.6$ were suppressed from further analysis, which led to the exclusion of four items. The CFA was conducted again with the remaining items and showed satisfactory factor loadings and model fit $\chi^{2}=225.49, \mathrm{df}=174, \mathrm{P}<0.05, \chi^{2} / \mathrm{df}=1.30, \mathrm{IFI}=0.99, \mathrm{CFI}=0.99, \mathrm{RMSEA}=$ 0.04).

To evaluate the convergent validity of the refined instrument, the standardised factor loadings were examined first. All the factor loadings are significant and above the acceptable level of 0.6 and the majority are above the ideal level of 0.7 (Hair et al., 2010). Moreover, all the construct reliabilities for the corresponding constructs are above 0.7 (Fornell and Larcker, 1981). All the Cronbach's alpha values are above or close to the acceptable level of 0.7 (Nunnally, 1978). Furthermore, all the AVEs (average variance extracted) for the corresponding constructs are above 0.5 , indicating that the AVE by each construct exceeds the variance due to measurement error for that construct (Fornell and Larcker, 1981). Overall, the convergent validity of the instrument is found to be acceptable (Table 1 ).

To examine the discriminant validity of the instrument, the AVE for each construct was compared against the squared factor correlations between that construct and other constructs. As shown in 
Table 1, most of the squared factor correlations between each construct are below the corresponding AVEs, suggesting satisfactory discriminant validity (Fornell and Larcker, 1981). Interestingly, the squared factor correlations between the three EEB constructs are above their corresponding AVEs. As noted by Moore and Benbasat (1991) conceptual dimensionality should be distinguished from empirical dimensionality, in that constructs are conceptually different although they tend to be viewed identically by the respondents. Given that the three constructs measure the environmental and ethical CR behaviours and were developed according to the substantive theories, it is not surprising to see high correlations between these constructs. As Bollen and Hoyle (1990) point out, high or perfect correlation is not a sufficient condition to claim that a concept is unidimensional rather than bi-dimensional. We re-examined the three EEB constructs against the theory, and noting their distinct conceptual differences, and their different positions in the implementation stages framework proposed by Carlisle and Faulkner (2004), in this research they are retained as separate constructs in the following analysis. The final measurement items are reported in the Appendix 1.

[Take in Table 1 about here]

\section{Results}

\subsection{Direct effects}

Our hypotheses were tested using SEM with a maximum likelihood estimation option and our conceptual model (Figure 1) as the base model (M1). We first examined the base model. The model fits the data satisfactorily $\left(\chi^{2}=470.90, \mathrm{df}=180, P<0.005, \chi^{2} / \mathrm{df}=2.62, \mathrm{IFI}=0.91, \mathrm{CFI}=0.91, \mathrm{RMSEA}=\right.$ 0.10). Table 2 summarises the results.

With regard to hypotheses $\mathrm{H} 1 \mathrm{a}, \mathrm{H} 1 \mathrm{~b}$ and $\mathrm{H} 1 \mathrm{c}$, Table 2 shows that partnership orientation relates positively to the internal awareness of EEB values and outcomes (path coefficient $=0.23, t=2.33$ ), to the monitoring of EEB performance (path coefficient $=0.30, t=3.02$ ), and to the sharing of EEB best practices (path coefficient $=0.17, t=1.86$ ) respectively. All three hypotheses are therefore supported.

Hypothesis $\mathrm{H} 2 \mathrm{a}$ and $\mathrm{H} 2 \mathrm{~b}$ pertain to the effects of the internal awareness of EEB values and outcomes. The results (Table 2) show that the internal awareness of EEB values and outcomes is positively related to management appreciation of the relational risks (RR) associated with partnering ( path coefficient $=0.29, t=2.90)$, but not to the performance risks $(P R)$ associated with partnering . 
For hypotheses $\mathrm{H} 3 \mathrm{a}$ and $\mathrm{H} 3 \mathrm{~b}$, which concern the effect of monitoring EEB performance, we find that such monitoring is positively related to management appreciation of the relational risks (path coefficient $=0.32, t=3.18$ ), thus supporting $\mathrm{H} 3 \mathrm{a}$, but not to management appreciation of the performance risks.

The sharing of CR best practices is positively associated with management appreciation of both the relational risks (path coefficient $=0.18, \mathrm{t}=2.02$ ) and the performance risks associated with partnering ( path coefficient $=0.25, t=2.57$ ).

Thus, our results show that all three facets of environmental and ethical behaviour contribute to better management appreciation of relational risk ( $\mathrm{H} 2 \mathrm{a}, \mathrm{H} 3 \mathrm{a}$ and $\mathrm{H} 4 \mathrm{a}$ supported); however, only the sharing of EEB best practices is shown to lead to better management appreciation of the performance risks (H4b supported).

\subsection{Mediating effect of corporate responsibility}

We followed the procedure recommended by Hair et al. (2010) to examine the mediating role of EEB. Table 3 shows the results of adding a direct path to the base model (M1), between supply chain partnership (SCP) and management appreciation of relational risk (RR). The revised model (M1.1) fits the data satisfactorily $\left(\chi^{2}=470.82, \mathrm{df}=179, P<0.005, \chi^{2} / \mathrm{df}=2.63, \mathrm{IFI}=0.91, \mathrm{CFI}=0.91, \mathrm{RMSEA}=\right.$ 0.10). The direct effects observed in the base model were repeated with the exception that this time the sharing of EEB best practices was shown to be positively related to the management appreciation of the performance risks associated with partnering $(\mathrm{H} 4 \mathrm{~b})$ only, and hence not to the relational risks (i.e. H4a rejected). Table 3 shows that hypothesis 5 a was therefore supported, but in a slightly more limited way than expected. In other words, the results confirm that a partnership orientation does not directly lead to better management appreciation of the relational risks (direct path is non-significant). Adding the direct path between partnership orientation and management appreciation of relational risks did not improve the model fit significantly (chi-square change is nonsignificant, $\left.\Delta \chi^{2}=-0.08, \Delta d f=-1\right)$. Thus, model M1.1 confirms that:

The internal awareness of EEB values and outcomes and the monitoring of EEB performance do mediate between partnership orientation and management appreciation of relational risk (RR).

Table 4 shows the mediation effect in relation to performance risk (PR). It presents the results of adding a direct path to the base model (M1), between supply chain partnership (SCP) and management appreciation of performance risk (PR). The revised model (M1.2) fits the data satisfactorily $\left(\chi^{2}=471.17, \mathrm{df}=179, P<0.005, \chi^{2} / \mathrm{df}=2.63, \mathrm{IFI}=0.91, \mathrm{CFI}=0.91, \mathrm{RMSEA}=0.10\right)$. The direct effects observed in the base model were replicated exactly in model M1.2. That is to say, H1a, 
$\mathrm{H} 1 \mathrm{~b}, \mathrm{H} 1 \mathrm{c}, \mathrm{H} 2 \mathrm{a}, \mathrm{H} 3 \mathrm{a}, \mathrm{H} 4 \mathrm{a}$ and $\mathrm{H} 4 \mathrm{~b}$ were all supported. Table 4 also shows that a partnership orientation does not directly lead to better management appreciation of the performance risks (direct path and chi-square change are non-significant, $\Delta \chi^{2}=0.27, \Delta d f=-1$ ), and therefore that hypothesis $5 b$ was supported. In other words, model M1.2 confirms that:

The sharing of EEB best practices does mediate between partnership orientation and management appreciation of performance risk (PR).

[Take in Table 2, Table 3 and Table 4 about here]

\section{Discussion}

In general terms, this paper contributes to two salient fields of research. Firstly, to the increasingly significant area concerned with green supply chain design and operations (Kumar et al., 2012). Secondly, it contributes to the development of the relatively young, but growing and increasingly relevant area, of supply chain risk management research (Christopher and Peck, 2004; Jia and Rutherford, 2010; Colicchia and Strozzi, 2012). The supply chain partnership literature stresses the importance of 'trust' and points out that 'trust' is a key determinant of supply chain partnership success (He et al., 2011; Wu et al., 2012). The extant literature also points out that firms practising corporately responsible EEBs are better at anticipating risk. However, these studies implicitly draw on transactional theory and do not explicitly explain how $x$ results in $y$. Likewise, the supply chain literature does not explain how in practice a firm can go about developing trust, and the green supply chain literature does not explicitly address partnership. In this study we open the black box and offer a theoretically based reasoning as to why supply chain partnership and EEB result in better appreciation of risk. In doing so, we offer a decision support mechanism to practising managers.

Our findings contribute to the literature examining executives' and managers' considerations and choices regarding allocating scarce resources to developing supply chain partnership and green practice implementation (Shavit and Adam, 2011). Our findings indicate that, at the functional level and in the context of buyer-supplier partnerships, investment of resources in green practices alongside supply chain partnership does pay off. The findings lend weight to the argument that investing in CR/EEB can be viewed as a shrewd method for reducing a firm's risk exposure by generating trust among supply chain partners, and hence as a supply chain risk management approach (Cruz, 2013). More broadly, our findings suggest that investing in CR/EEB is a route to building more robust relationships with important supply chain stakeholders. Our findings also provide direct support for the view that CR should reflect the idea that responsibilities are integral to corporate behaviours, actions, decisions and impacts, in contrast to its close relation social 
responsibility, which instead connotes the discretionary responsibilities of business (Carroll, 1979; Surroca et al., 2010).

Our findings confirm our proposition that simply entering into partnerships, or increasing the prevalence of a partnering orientation with main suppliers, does not in itself facilitate the appreciation of the potential risks of partnering that, with the increasing need for firms to be agile and responsive, is nowadays crucial. This is an important finding because it indicates that any managerial assumption that simply getting closer to suppliers will help the firm to reduce risk exposure within the supply chain is likely to be flawed. Instead, our findings confirm the influential role of green, $\mathrm{CR}$ behaviours/practices at the functional level within the firm.

We have established that an EEB ethos within a firm, evidenced through internal awareness, monitoring and sharing best practice activities, enhances management's appreciation of the risks associated with partnering. Thus our results indicate that the full range of EEB practices (i.e. awareness, monitoring and sharing best practice), and not just specific ones, leads to enhanced management appreciation of the relational risk associated with partnership, and that EEB best practice sharing leads to enhanced management appreciation of the performance risk associated with partnering. Secondly, we have established that although a partnering orientation itself is not sufficient to ensure management's appreciation of the risks of entering partnership relationships, it is a good predictor of a firm's propensity to embrace EEB. Thirdly, we have established that EEB mediates the relationship between partnership orientation and management appreciation of the risks of partnering.

Our findings have two main theoretical implications. Firstly, our findings indicate that CR/EEB directly affect firms' appreciation of the risks of partnering. The findings thereby add to the extant literature rooted in institutional theory, which views $\mathrm{CR} / \mathrm{EEB}$ as a set of implementable deliberate and demonstrable actions that enable firms to enhance their legitimacy among their suppliers, and in turn develop greater information flow from suppliers to inform decision-making.

Secondly, our findings indicate that a partnership approach, although characterised by loose contractual agreements and the absence of legal structures, has significant merit in contemporary supply chain design, when accompanied by the promulgation of risk revealing EEB. Our findings thereby add to the extant literature that focuses primarily on, endorses and aligns towards the relational view of the firm (Dyer and Sigh, 1998) as opposed to the new institutional economics theoretical perspective (Williamson, 2000) for example, which instead places partnership as a riskladen proposition. 
Our findings also confirm that the relationship between supply chain partnership and supply chain risk management is not straightforward. In doing so, they provide new insight, helping to fill the gap in the literature about the processes that can be used to minimise risk for supply chain members (Arnold et al., 2010). This has extended the supply chain risk management literature (Cruz, 2013), by both confirming the limitation of partnership per se as a risk mitigating mechanism and identifying the need for intervening mechanisms to help properly realise risk management in the supply chain context.

As has been noted by a variety of authors (Beekman and Robinson, 2004; Handley and Benton, 2009) there are many examples of firms that have entered into partnerships as a means of improving business performance only to be disappointed at the outcomes. Indeed, it is the risks associated with collaborative supply chain relationships, according to Arnold et al. (2010), that have often been identified as one of the primary limiting factors on the growth of such relationships (Aron et al., 2005; Goh et al., 2007). The findings of this study, by identifying how managers can gain a deeper appreciation of the risks of a partnering approach, helps to offset this limiting factor and therefore should help to facilitate the growth of such relationships. Typically, cooperative relationships bring risk and leave an organisation vulnerable if they are not controlled during the stages of relationship formulation and commitment building (Kumar and van Dissel, 1996; Arnold et al., 2010). The findings of this study indicate that managers can reduce such vulnerability by providing the necessary control of risk through investing in CR/EEB.

A further important contribution of this study is that it explicitly considers relational risk in its own right as a component of supply chain related risk. This is an important departure from much of the existing literature on supply chain risk, which as Jia and Rutherford (2010) note is heavily focused on performance risk sources and mitigation (Tang 2006; Zsidisin, 2003). In contrast, relational risk sources and mitigation (Christopher and Lee, 2004; Das and Teng, 2001; Delerue, 2004) have received little attention (Jia and Rutherford, 2010).

\subsection{Managerial implications}

Our results indicate that an important strategy firms can adopt for developing a good understanding of the risks of partnering is an undertaking and commitment to $C R$, which itself is more likely to take root and improve when the firm embraces a close relationship ethos as part of its supply strategy. Our findings therefore have several managerial implications in relation to green supply chain design.

Each of the EEB practices comprising our three EEB construct variables are in themselves practices that directly and practically can green the supply chain, for example regular independent audits of 
commercial and environmental integrity if undertaken by increasing numbers of firms in the supply chain, and likewise incorporating the findings from independent environmental audits within internal or external training programmes. However, there is an equally important new insight and implication from our findings for greening the supply chain. It is widely agreed that it is vital that firms not only increasingly green their supply chain, but green it in a sustainable way, that is, with a long-term rather than short-term green perspective. They can do this individually, or through some form of collective means. Partnership is an attempt to build relationships for long term viability rather than short-term (and short-lived) gain. A better understanding of the relational and performance risks associated with partnering, driven through the implementation of EEB, is likely to lead to more durable partnerships. Partnerships that have longevity are, in turn, arguably better able, firstly, to facilitate the permeation and spread of green practices within the supply chain but, secondly, and arguably more importantly, to permit these environmental and ethical practices to be properly and more permanently embedded. Thus the reduction in the likelihood of exposure to partnership risks is likely to convert transient green supply chain policies, into long-lasting green supply chain practices and systems.

Given the potentially tremendous costs to the firm of not understanding, and hence not mitigating against or comprehensively managing the risks associated with partnering, we can conclude that buying into $C R / E E B$ and investing in those practices that realise a CR/EEB ethos is an opportunity that firms should not miss or take lightly. Our findings indicate that CR/EEB is not a fad or a luxury, but in the context of firms' management of their suppliers and in particular strategic supplier relationships, it is essential. By implication, the sooner that firms embrace CR/EEB, the sooner they are likely to reduce their risk exposure when partnering, and the less likelihood there is that unintended and undesirable consequences will flow from their otherwise well intentioned efforts to establish closer supplier relationships. Our study indicates that tactically this can be achieved with a variety of measures. Of particular practical value to managers, the study has identified the specific EEB practices that are relevant to enhancing managers' appreciation of the risk of partnerships. This is a further benefit of this study's approach of operationalising (i.e. measuring) EEB through tangible practices, rather than through more abstract principles/statements of intent, as has been the case with many prior studies on greening supply chains. The practical measures that managers can immediately implement include developing a values statement and ethical framework on what constitutes acceptable business practices, conducting regular independent audits of environmental integrity, incorporating findings of independent environmental audits or monitoring practices within training programmes with partners, and incorporating environmental and ethical standards within partnering strategies. 
Furthermore, while a number of these EEB practices will require managerial effort and monetary investment to implement, others such as creating a values statement and ethical framework on acceptable environmental practices will require very little investment, or are relatively simple extensions to existing business practices.

It is important that managers appreciate the risks that can accompany a partnership relationship approach (Hallikas et al., 2004). It is important that they have a good understanding of the potential risks. The findings of this study indicate that investing in CR/EEB is essential to help managers to avoid making potentially costly investments in their relationships with suppliers that then fail to deliver the expected outcomes (Dekker et al., 2013). Furthermore, and consequently, that investing in CR/EEB is likely to help managers to make better informed decisions about who to partner with and when (Carl, 2008), and can help them to more judiciously appraise the relationships, and in turn to better define the boundaries, scope and/or main activities involved in partnering relationships.

The results of the study also have valuable practical utility for those policy makers such as national and local government, tasked with persuading firms of the need to invest in greening the supply chain. It provides them with empirical support for convincing firms of the value, to their wider efforts to improve collaboration and performance within the supply chain, of deliberately investing in a green policy perspective by developing an EEB and CR ethos.

\subsection{Limitations and further research}

This study has a number of limitations. Our research has confirmed a positive relationship between EEB in terms of internal awareness, monitoring and sharing best practice, and better managerial understanding of the risk associated with supplier partnerships. However, despite our confirmatory testing, our measures of the CR and risk constructs require further validation in different contexts. Furthermore, new measurement items, particularly for $E E B / C R$, are likely to emerge in the literature quickly, and these need to be incorporated into similar analyses of the mediating role. Future studies may also wish to extend our analysis by considering how other aspects of risk may or may not be affected by the presence or absence of EEB.

We have noted above a number of managerial actions that our study has confirmed should advance managerial appreciation of relational and performance risk. More in-depth research is now needed to examine how these actions can be most effectively implemented. Moreover, an examination of the causal linkages at a more fine-grained dimensional level would also be beneficial. For example, further research is needed to establish how each of the contributing awareness, monitoring or best practice sharing activities can be leveraged, not only to maximise their impact on helping managers 
to reduce relational or performance risk, but also to help managers to better construct the justifications they are likely to continue to need to make for the prioritisation of scarce resources towards CR practices.

Our study has established the relevance of $C R$ to one of the core functional strategies within the firm - supply chain management. Investigation of CR's relevance to other functional strategy areas is strongly encouraged. 


\section{References}

Akacum, A. and B. G. Dale. 1995. "Supplier partnering: case study experiences." International Journal of Purchasing and Materials Management 31 (4), 37-44.

Armstrong, J. S. and T. S. Overton. 1977. "Estimating nonresponse bias in mail surveys." Journal of Marketing Research 14 (August 1977): 396-402.

Arnold, V., T. Benford, C. Hampton, and S. G. Sutton. 2010. "Competing pressures of risk and absorptive capacity potential on commitment and information sharing in global supply chains." European Journal of Information Systems 19 (1): 134-152.

Aron, R., K. Clemons, and S. Reddi. 2005. "Just right outsourcing: understanding and managing risk." Journal of Management Information Systems 22 (2): 37-55.

Baier, C., E. Hartmann, and R. Moser. 2008. "Strategic alignment and purchasing efficacy: an exploratory analysis of their impact on financial performance." Journal of Supply Chain Management 44 (4): 36-52.

Bhattacharya, C. B. and S. Sen. 2001. "Does doing good always lead to doing better? Consumer reactions to corporate social responsibility." Journal of Marketing Research 38 (2): 225-243.

Beekman, A. V. and R. B. Robinson. 2004. "Supplier partnerships and the small, high-growth firm: selecting for success." Journal of Small Business Management 42 (1): 59-77.

Bollen, K. A. and R. H. Hoyle. 1990. "Perceived cohesion: a conceptual and empirical examination." Social Forces 69 (2): 470-504.

Bowman, E. H. 1980. "A risk/return paradox for strategic management." Sloan Management Review $21(3): 17-31$.

Carl, H. 2008. "Supporting partner identification for virtual organisations in manufacturing." Journal of Manufacturing Technology Management 19 (4): 497-513.

Carlisle, Y. M. and D. O. Faulkner. 2004. "Corporate social responsibility: a stages framework." European Business Journal 16 (4): 143-151.

Carr, A .S., H. Kaynak, J. L. Hartley and A. Ross, A. 2008. "Supplier dependence: impact on supplier's participation and performance." International Journal of Operations and Production Management 28 (9): 899-916.

Carroll, A. B. 1979. "A three-dimensional conceptual model of corporate performance." Academy of Management Review 4 (4): 497-505.

Cheung, D. K. K., R. J. Welford, and P. R. Hills. 2009. "CSR and the environment: business supply chain partnerships in Hong Kong and PRDR, China." Corporate Social Responsibility and Environmental Management 16 (5): 250-263.

Chiles, T. H. and J. F. McMackin. 1996. "Integrating variable risk preferences, trust, and transaction cost economics." Academy of Management Review 21 (1): 73-99. 
Christopher, M. and H. Lee. 2004. "Mitigating supply chain risk through improved confidence." International Journal of Physical Distribution and Logistics Management 34 (5): 388-396.

Christopher, M. and H. Peck. 2004. "Building the resilient supply chain." The International Journal of Logistics Management 15 (2): 1-13.

Colicchia, C. and F. Strozzi. 2012. "Supply chain risk management: a new methodology for a systematic literature review." Supply Chain Management: An International Journal 17 (4): 403-418.

Cruz, J. M. 2009. "The impact of corporate social responsibility in supply chain management: multicriteria decision-making approach." Decision Support Systems 48 (1): 224-236.

Cruz, J. M. 2013. "Mitigating global supply chain risks through corporate social responsibility." International Journal of Production Research 51 (13): 3995-4010.

Cruz, J. M. and D. Matsypura. 2009. "Supply chain networks with corporate social responsibility through integrated environmental decision-making." International Journal of Production Research 47 (3): 621-648.

Das, T. K. and B-S. Teng. 1996. "Risk types and inter-firm alliance structures." Journal of Management Studies 33 (6): 827-843.

Das, T. K. and B-S. Teng. 2001. "Relational risk and its personal correlates in strategic alliances." Journal of Business and Psychology 15 (3): 449-464.

Dekker, H. C., J. Sakaguchi, and T.Kawai. 2013. "Beyond the contract: managing risk in supply chain relations." Management Accounting Research 24 (2): 122-139.

Delerue, H. 2004. "Relational risks perception in European biotechnology alliances: the effect of contextual factors." European Management Journal 22 (5): 546-556.

Dillman, D. A. 2000. Mail and Internet Surveys: The Tailored Design Method. 2nd Edn. New York: John Wiley Co.

DiMaggio, P. and W. Powell. 1983. "The iron cage revisited: institutional isomorphism and collective rationality in organizational fields." American Sociological Review 48: 147-160.

Dyer, J. H. and H. Singh. 1998. "The relational view: cooperative strategy and sources of interorganizational competitive advantage." Academy of Management Review, 23 (4): 660-679.

Faisal, M. N., D. K. Banwet, and R. Shankar. 2006. "Mapping supply chains on risk and customer sensitivity dimensions." Industrial Management and Data Systems 106 (5/6): 878-895.

Feldman, S., P. Soyka, and P. Ameer. 1997. “Does improving a firm's environmental management system and environmental performance result in a higher stock price?" Journal of Investing 6 (4): 8797.

Fombrun, C. J. 2005. "The leadership challenge: building resilient corporate reputations." In: J. P. Doh and S. A. Stumpf (Eds.) Handbook on Responsible Leadership and Governance in Global Business.

Cheltenham: Edward Elgar. 
Fornell, C. and D. F. Larker. 1981. "Evaluating structural equation models with unobservable variables and measurement error." Journal of Marketing Research 18 (1): 39-50.

Frankel, R., J. S. Whipple, and D. J. Frayer. 1996. "Formal versus informal contracts: Achieving alliance success." International Journal of Physical Distribution \& Logistics Management, 26 (3): 47-63.

Fynes, B., C. Voss, and S. de Burca. 2005. "The impact of supply chain relationship dynamics on manufacturing performance." International Journal of Operations and Production Management 25 (1): 6-19.

Gallear, D., A. Ghobadian and W-F Chen. 2012. "Corporate social responsibility, supply chain partnership and performance: an empirical examination.", International Journal of Production Economics 140 (1): 83-91.

Ghobadian, A., D. Gallear and M. Hopkins. 2007. "TQM and CSR nexus." International Journal of Quality and Reliability Management 24 (7): 704-721.

Goh, M., J. Y. S. Lim, and F. Meng. 2007. "A stochastic model for risk management in global supply chain networks." European Journal of Operations Research 182: 164-173.

Hair, J. F., W. C. Black, B. J. Babin, and R. E. Anderson. 2010. Multivariate Data Analysis, 7th edn. London: Pearson Prentice-Hall.

Hallikas, J., I. Karvonen, U. Pulkkinen, V-M. Virolainen, and M. Tuominena. 2004. "Risk management processes in supplier networks." International Journal of Production Economics 90 (1): 47-58.

Handley, S. M. and W. C. Benton Jr. 2009. "Unlocking the business outsourcing process model." Journal of Operations Management 27 (5): 334-361.

Hart, S. L. 1995. "A natural-resource-based view of the firm." Academy of Management Review 20 (4): 966-1014.

He, Q., D. Gallear, and A. Ghobadian. 2011. "Knowledge transfer: the facilitating attributes in supplychain partnerships." Information Systems Management 28 (1), 57-70.

Heal, G. 2008. When Principles Pay, Corporate Social Responsibility and the Bottom Line. New York: Columbia University Press.

Hendricks, K. B. and V. R. Singhal. 2005. "An empirical analysis of the effects of supply chain disruption on long-run stock price performance and equity risk of the firm." Production and Operations Management, 14 (1): 35-52.

Hillenbrand, C., K. Money, and A. Ghobadian. 2013. "Unpacking the mechanism by which corporate responsibility impacts stakeholder relationships." British Journal of Management 24 (1): 127-146.

Hofer, C. W. and D. Schendel. 1978. Strategy Formulation: Analytical Concepts. St Apul: West Publishing.

Holt, D. and A. Ghobadian. 2009. "An empirical study of green supply chain management practices amongst UK manufacturers." Journal of Manufacturing Technology Management 20 (7): 933-956. 
Hopkins, M. 2005. "Measurement of corporate social responsibility." International Journal of Management and Decision Making 6 (3/4): 213-231.

Hughes, J., M. Ralf, and W. Michels. 1999. Transform Your Supply Chain. London: International Thomson.

Husted, B. W. 2005. "Risk management, real options, and corporate social responsibility." Journal of Business Ethics 60 (2): 175-183.

Jia, F. and C. Rutherford. 2010. "Mitigation of supply chain relational risk caused by cultural differences between China and the West." International Journal of Logistics Management 21 (2): 251-270.

Jo, H. and H. Na. 2012. "Does CSR reduce firm risk? Evidence from controversial industry sectors." Journal of Business Ethics 110 (4): 441-456.

Johnson, M. E. 2001. "Learning from toys: lessons in managing supply chain risk from toy industry." California Management Review 43: 106-130.

Joreskog, K. G. and D. Sorbom. 2004. Lisrel 8.70. Lincolnwood USA: Scientific Software International, Inc.

Jüttner , U., H. Peck., and M. Christopher. 2003. "Supply chain risk management: outlining an agenda for future research." International Journal of Logistics Research and Applications 6 (4): 197-210.

Katner, R. M. 1989. "Becoming PALS: pooling, allying, and linking across companies." Academy of Management Executive 3 (3): 183-193.

Khan, O. and B. Burnes. 2007. "Risk and supply chain management: creating a research agenda." International Journal of Logistics Management 18 (2): 197-216.

Kline, R. 2011. Principles and Practices of Structural Equation Modelling (3rd Edn.). New York: The Guilford Press.

Krishnan, R., X. Martin, and N. G. Noorderhaven. 2006. "When does trust matter to alliance performance?" Academy of Management Journal 49 (5): 894-917.

Kumar, K. and H. G. van Dissel. 1996. "Sustainable collaboration: managing conflict and cooperation in interorganizational systems." MIS Quarterly 20 (3): 279-300.

Kumar, N., L. W. Stern, and J, C. Anderson. 1993. "Conducting interorganisational research using key informants." Academy of Management Journal 36 (6): 1633-1651.

Kumar, S., S. Teichman, and T. Timpernagel. 2012. "A green supply chain is a requirement for profitability." International Journal of Production Research 50 (5): 1278-1296.

Lacey, R., A. G. Close, and R. Z. Finney. 2010. "The pivotal roles of product knowledge and corporate social responsibility in event sponsorship effectiveness." Journal of Business Research 63 (11): 12221228. 
Lagenspetz, O. 1992. "Legitimacy and trust." Philosophical Investigations 15 (1): 1-21.

Lambert, D. M., M. A. Emmelhainz, and J. T. Gardner. 1996a. "So you think you want a partner?" Marketing Management 5 (2): 24-30.

Lambert, D. M., M. A. Emmelhainz, and J. T. Gardner. 1996b. "Developing and implementing supply chain partnerships." International Journal of Logistics Management 7 (2): 1-17.

Laplume, A. O., K. Sonpar, and R. A. Litz. 2008. "Stakeholder theory: reviewing a theory that moves us." Journal of Management 34 (6): 1152-1189.

Leavy, B. 1994. "Two strategic perspectives on the buyer-supplier relationship." Production and Inventory Management Journal 35 (2): 47-51.

Lebas, M. J. 1995. "Performance measurement and performance management." International Journal of Production Economics 41 (1/3): 23-35.

Lemke, F., K. Goffin, and M. Szwejczewski. 2003. "Investigating the meaning of suppliermanufacturer partnerships: an exploratory study." International Journal of Physical Distribution and Logistics Management 33 (1/2): 12-35.

Lewicki, R. J., D. J. McAllister, and R. J. Bies. 1998. "Trust and distrust: new relationships and realities." Academy of Management Review 23 (3): 438-458.

Lewis, M. A. 2003. "Cause, consequence and control: towards a theoretical and practical model of operational risk." Journal of Operations Management 21 (2): 205-224.

Li, S., B. Ragu-Nathan, T. S. Ragu-Nathan, and S. S. Rao. 2006. "The impact of supply chain management practices on competitive advantage and organisational performance." Omega 34 (2): 107-124.

Lu, W., W. Wang and H. Lee. 2013. "The relationship between corporate social responsibility and corporate performance: evidence from the US semiconductor industry." International Journal of Production Research 51 (19): 5683-5695.

MacBeth, D. K. and N. Ferguson. 1994. Partnership Sourcing: An Integrated Supply Chain Management Approach. London: Pitman Publishing.

Maheshwari, B., V. Kumar, and U. 2006. "Optimizing success in supply chain partnerships." Journal of Enterprise Information Management 19 (3): 277-291.

McDonald, F. 1999. "The importance of power in partnership relationships." Journal of General Management 25 (1): 43-59.

Madsen, H. and J. P. Ulhoi. 2001. "Greening of human resources: environmental awareness and training interests within the workforce." Industrial Management and Data Systems 101 (2): 57-65.

Maloni, M. J. and W. C. Benton. 1997. "Supply chain partnerships: opportunities for operations research." European Journal of Operational Research 101: 419-429. 
Mentzer, J., S. Min, and Z. G. Zacharia. 2000. "The nature of interfirm partnering in supply chain management." Journal of Retailing 74 (4): 549-568.

Mesquita, L. F. 2007. "Starting over when the bickering never ends: rebuilding aggregate trust among clustered firms through trust facilitators." Academy of Management Review 32 (1): 72-91.

Meyer, J. W. and B. Rowan. 1977. "Institutionalized organizations: formal structure as myth and ceremony." American Journal of Sociology 83 (2): 340-363.

Mitchell, R. K., B. R. Agle, and D. J. Wood. 1997. "Toward a theory of stakeholder identification and salience: defining the principle of who and what really counts." Academy of Management Review 22 (4): 853-886.

Mitchell, V. W. 1995. "Organizational risk perception and reduction: a literature review." British Journal of Management 6 (2): 115-133.

Mohr, J. and R. Spekman. 1994. "Characteristics of partnership success: partnership attributes, communication behaviour, and conflict resolution techniques." Strategic Management Journal 15 (2): 135-142.

Moore, G. C. and I. Benbasat. 1991. "Development of an instrument to measure the perceptions of adopting an information technology innovation." Information Systems Research 2 (3): 192-222.

Nooteboom, B., H. Berger, and N. G. Noorderhaven. 1997. "Effects of trust and governance on relational risk." Academy of Management Journal 40 (2): 308-338.

Nunnally, J. C. 1978. Psychometric Theory, 2nd edn. New York: McGraw-Hill.

Orlitzky, M., and J. D. Benjamin. 2001 "Corporate social responsibility and firm risk: a meta-analytic Review." Business and Society 40 (4): 369-396.

Paine, L. S. 2003. Value Shift: Why Companies Must Merge Social and Financial Imperatives to Achieve Superior Performance. New York: McGraw-Hill.

Park-Poaps, H. and K. Rees. 2010. "Stakeholder forces of socially responsible supply chain management orientation." Journal of Business Ethics 92 (2): 305-322.

Parker, C. 2002. The Open Corporation. Cambridge: Cambridge University Press.

Pekar, P. and R. Allio. 1994. "Making alliances work: Guidelines for success." Long Range Planning, 27 (4): 54-65.

Phillips, L. W. 1981. "Assessing measurement error in key informant reports: a methodological note on organizational analysis in marketing." Journal of Marketing Research 18 (11): 395-415.

Rao, P. and D. Holt. 2005. "Do green supply chains lead to competitiveness and economic performance?" International Journal of Operations \& Production Management 25 (9): 898-916. 
Ren, S. J., E. W. T. Ngai, and V. Cho. 2010. "Examining the determinants of outsourcing partnership quality in Chinese small- and medium-sized enterprises." International Journal of Production Research 48 (2): 453-475.

Rousseau, D. M., S. B. Sitkin, R. S. Burt, and C. Camerer. 1998. "Introduction to Special Topic Forum. Not so different after all: a cross-discipline view of trust." Academy of Management Review 23 (3): 393-404.

Rowe, W. D. 1977. An Anatomy of Risk. New York: Wiley.

Salama, A., K. Anderson, and J. S.Toms. 2011. "Does community and environmental responsibility affect firm risk? Evidence from UK panel data 1994-2006." Business Ethics: A European Review 20 (2): 192-204.

Schumacker, R. E. and R. G. Lomax. 2004. A Beginner's Guide to Structural Equation Modeling (2nd Edn.). London: Lawrence Erlbaum Associates, Publishers.

Schwartz, P. and B. Gibb. 1999. When Good Companies Do Bad Things. New York: Wiley.

Shavit, T. and A. M. Adam. 2011. "A preliminary exploration of the effects of rational factors and behavioral biases on the managerial choice to invest in corporate responsibility" Managerial and Decision Economics 32 (3): 205-213.

Stuart, F. I. 1997. "Supply-chain strategy: organizational influence through supplier alliances." British Journal of Management 8 (3): 223-236.

Suchman, M. C. 1995. "Managing legitimacy: strategic and institutional approaches." Academy of Management Review 20 (3): 571-610.

Surroca, J., J. A. Tribó, and S. Waddock. 2010. “Corporate responsibility and financial performance: the role of intangible resources." Strategic Management Journal 31 (5): 463-490.

Tang, C. S. 2006. "Perspectives in supply chain risk management." International Journal of Production Economics 103 (2): 451-488.

Taylor, A. 2005. "An operations perspective on strategic alliance success factors: an exploratory study of alliance managers in the software industry." International Journal of Operations and Production Management 25 (5): 469-490.

Trent, R. J. 2005. "Why relationships matter." Supply Chain Management Review 9 (8): 53-59.

UNSRID. 2002. Regulating Business Via Multi-Stakeholder Initiatives: A Preliminary Assessment in Voluntary Approaches to Corporate Responsibility: Readings and Resource Guide. Geneva: NGLS.

Vachon, S. and R. D. Klassen. 2006. "Extending green practices across the supply chain." International Journal of Operations and Production Management 26 (7): 795-821.

Vancheswaran, A. and V. Gautam, V. 2011. "CSR in SMEs: exploring a marketing correlation in Indian SMEs." Journal of Small Business and Entrepreneurship 24 (1): 85-98. 
Vaus, D. D. 2004. Surveys in Social Research (5th Edn.). London: Routledge.

Virolainen, V-M. 1998. "A survey of procurement strategy development in industrial companies." International Journal of Production Economics 56/57: 677-688.

Waddock, S. A., C. Bodwell, and S. B. Graves. 2002. "Responsibility: the new business imperative." Academy of Management Executive 16 (2): 132-148.

Waddock, S. 2004. "Parallel universes: companies, academics, and the progress of corporate citizenship." Business and Society Review 109 (1): 5-42.

Waddock, S. 2008. "The development of corporate responsibility/corporate citizenship." Organization Management Journal 5 (1): 29-39.

Wallace, L., M. Keil, and A. Rai. 2004. "How software project risk affects project performance: an investigation of the dimensions of risk and an exploratory model." Decision Sciences 35 (2): 289-321.

Welford, R. and S. Frost. 2006. "Corporate social responsibility in Asian supply chains." Corporate Social Responsibility and Environmental Management 13 (3): 166-176.

Williamson, O. E. 2000. "The new institutional economics: taking stock, looking ahead." Journal of Economic Literature 38 (3): 595-613.

Wakolbinger, T. and J. M. Cruz. 2011. "Supply chain disruption risk management through strategic information acquisition and sharing and risk-sharing contracts." International Journal of Production Research 49 (13), 4063-4084.

Wilson, D. T. 1995. "An integrated model of buyer-seller relationships." Journal of the Academy of Marketing Science 23 (4): 335-345.

Wu, M-Y., Y-C Weng, and I-C Huang. 2012. "A study of supply chain partnerships based on the commitment-trust theory." Asia Pacific Journal of Marketing and Logistics 24 (4): 690-707.

Zineldin, M. and T. Bredenlow. 2003. "Strategic alliances: synergies and challenges." International Journal of Physical Distribution and Logistics Management 33 (5): 449-464.

Zsidisin, G. A. 2003. "Managerial perceptions of supply risk." Journal of Supply Chain Management 39 (1): 14-25. 


\section{EEB internal awareness*}

INTAWN2: a values statement and ethical framework on acceptable business practices

INTAWN3: publicising environmental and ethical statements to stakeholders

INTAWN4: task group(s) to examine potentially sensitive areas

Monitoring of EEB performance*

MONIT1: regular independent audits of commercial and environmental integrity

MONIT2: development of appropriate monitoring practices to ensure compliance with ethical policies

Sharing EEB best practices*

SHARBP1: incorporating findings of independent audits of commercial and environmental integrity or monitoring practices to ensure compliance with ethical policies within training programmes with partners

SHARBP2: $\quad$ using accreditation to ISO14000 Series (Environmental Management Systems Standard) to distinguish preferred supplier status

SHARPB3: incorporating environmental and ethical standards within partnering strategies

SHARBP4: incorporating findings of independent audits of commercial and environmental integrity or monitoring practices to ensure compliance with ethical policies within internal training programmes

Relational risk

RELRISK2: imbalance in resources

RELRISK3: imbalance in information sharing

RELRISK4: imbalance in accruing benefits

RELRISK5: premature trust

RELRISK6: conflict over the scope of the partnership

Performance risk

PERRISK1: partners failing to meet expectations

PERRISK2: loss of competitiveness

PERRISK3: risk of supply disruptions

Supply chain partnership

SCP1: $\quad$ view our key suppliers as suppliers of capabilities, not merely products and services

SCP2: $\quad$ engage extensively in two way exchange of important/technical information with key suppliers

SCP3: $\quad$ regularly involve suppliers in new product/service development

SCP4: make long-term commitment to suppliers to achieve mutually acceptable outcomes

SCP5: $\quad$ the benefits from problem solving with main suppliers are always shared jointly

Notes: *Adapted from Hughes et al., 1999 
Appendix 2. Covariance matrix of original items

\begin{tabular}{|c|c|c|c|c|c|c|c|c|c|c|c|c|c|c|c|c|c|c|c|c|c|c|c|c|c|}
\hline & 1 & 2 & 3 & 4 & 5 & 6 & 7 & 8 & 9 & 10 & 11 & 12 & 13 & 14 & 15 & 16 & 17 & 18 & 19 & 20 & 21 & 22 & 23 & 24 & 25 \\
\hline 1: SCP1 & 1.01 & & & & & & & & & & & & & & & & & & & & & & & & \\
\hline 2: SCP2 & 0.53 & 1.25 & & & & & & & & & & & & & & & & & & & & & & & \\
\hline 3 :SCP3 & 0.56 & 0.94 & 1.74 & & & & & & & & & & & & & & & & & & & & & & \\
\hline 4: SCP4 & 0.45 & 0.66 & 0.91 & 1.35 & & & & & & & & & & & & & & & & & & & & & \\
\hline 5: SCP5 & 0.59 & 0.79 & 0.98 & 0.91 & 1.41 & & & & & & & & & & & & & & & & & & & & \\
\hline 6: RELRISK1 & 0.10 & -0.03 & -0.06 & -0.04 & 0.15 & 1.02 & & & & & & & & & & & & & & & & & & & \\
\hline 7: RELRISK2 & -0.04 & -0.18 & -0.17 & -0.13 & -0.05 & 0.57 & 1.09 & & & & & & & & & & & & & & & & & & \\
\hline 8: RELRISK3 & 0.00 & 0.00 & 0.03 & 0.11 & 0.14 & 0.40 & 0.51 & 0.95 & & & & & & & & & & & & & & & & & \\
\hline 9: RELRISK4 & 0.10 & -0.06 & 0.02 & 0.06 & 0.19 & 0.32 & 0.52 & 0.61 & 0.95 & & & & & & & & & & & & & & & & \\
\hline 10: RELRISK5 & 0.04 & -0.03 & -0.10 & -0.01 & 0.06 & 0.46 & 0.50 & 0.43 & 0.37 & 0.91 & & & & & & & & & & & & & & & \\
\hline 11: RELRISK6 & -0.06 & -0.09 & 0.02 & 0.01 & 0.01 & 0.46 & 0.49 & 0.52 & 0.45 & 0.50 & 1.12 & & & & & & & & & & & & & & \\
\hline 12: RELRISK7 & 0.08 & 0.01 & 0.03 & -0.06 & 0.10 & 0.39 & 0.39 & 0.32 & 0.38 & 0.42 & 0.45 & 1.09 & & & & & & & & & & & & & \\
\hline 13: PERRISK1 & 0.04 & 0.15 & 0.08 & -0.01 & 0.03 & 0.18 & 0.23 & 0.31 & 0.22 & 0.22 & 0.23 & 0.19 & 0.93 & & & & & & & & & & & & \\
\hline 14 :PERRISK2 & 0.11 & 0.11 & 0.23 & 0.10 & 0.13 & 0.32 & 0.40 & 0.37 & 0.29 & 0.30 & 0.42 & 0.22 & 0.56 & 1.09 & & & & & & & & & & & \\
\hline 15 :PERRISK3 & 0.06 & 0.06 & 0.12 & 0.08 & 0.02 & 0.14 & 0.41 & 0.29 & 0.26 & 0.28 & 0.36 & 0.40 & 0.49 & 0.52 & 1.18 & & & & & & & & & & \\
\hline 16: INTAWN1 & 0.06 & 0.13 & 0.04 & 0.18 & 0.16 & 0.24 & 0.22 & 0.38 & 0.27 & 0.29 & 0.16 & 0.20 & 0.24 & 0.23 & 0.13 & 1.11 & & & & & & & & & \\
\hline 17: INTAWN2 & 0.11 & 0.12 & 0.19 & 0.15 & 0.31 & 0.34 & 0.33 & 0.36 & 0.28 & 0.31 & 0.31 & 0.36 & 0.24 & 0.27 & 0.20 & 0.45 & 1.21 & & & & & & & & \\
\hline 18: INTAWN3 & 0.04 & 0.02 & 0.05 & 0.13 & 0.23 & 0.41 & 0.45 & 0.34 & 0.35 & 0.48 & 0.33 & 0.42 & 0.10 & 0.17 & 0.30 & 0.38 & 0.78 & 1.34 & & & & & & & \\
\hline 19: INTAWN4 & 0.06 & 0.04 & -0.02 & 0.09 & 0.08 & 0.30 & 0.35 & 0.29 & 0.20 & 0.33 & 0.25 & 0.28 & 0.17 & 0.31 & 0.19 & 0.52 & 0.57 & 0.57 & 0.97 & & & & & & \\
\hline 20: MONIT1 & 0.14 & 0.14 & 0.13 & 0.13 & 0.27 & 0.37 & 0.34 & 0.39 & 0.32 & 0.39 & 0.32 & 0.37 & 0.18 & 0.26 & 0.32 & 0.41 & 0.56 & 0.71 & 0.44 & 0.97 & & & & & \\
\hline 21: MONIT2 & 0.17 & 0.24 & 0.20 & 0.22 & 0.27 & 0.34 & 0.40 & 0.38 & 0.29 & 0.40 & 0.28 & 0.33 & 0.13 & 0.19 & 0.27 & 0.47 & 0.57 & 0.67 & 0.44 & 0.72 & 1.04 & & & & \\
\hline 22: SHARBP1 & 0.01 & 0.12 & 0.10 & 0.10 & 0.12 & 0.28 & 0.32 & 0.38 & 0.27 & 0.35 & 0.38 & 0.34 & 0.18 & 0.27 & 0.29 & 0.43 & 0.62 & 0.66 & 0.45 & 0.64 & 0.70 & 1.03 & & & \\
\hline 23: SHARBP2 & -0.13 & -0.06 & -0.04 & -0.11 & -0.03 & 0.21 & 0.36 & 0.16 & 0.30 & 0.31 & 0.30 & 0.37 & 0.08 & 0.24 & 0.34 & 0.26 & 0.59 & 0.62 & 0.40 & 0.49 & 0.50 & 0.67 & 1.42 & & \\
\hline 24: SHARBP3 & -0.03 & 0.00 & 0.04 & 0.01 & 0.04 & 0.23 & 0.31 & 0.33 & 0.28 & 0.33 & 0.27 & 0.27 & 0.14 & 0.19 & 0.25 & 0.48 & 0.53 & 0.63 & 0.41 & 0.58 & 0.64 & 0.72 & 0.71 & 1.06 & \\
\hline 25: SHARBP4 & 0.00 & 0.14 & 0.08 & 0.11 & 0.14 & 0.27 & 0.34 & 0.38 & 0.28 & 0.36 & 0.38 & 0.41 & 0.29 & 0.29 & 0.36 & 0.51 & 0.70 & 0.67 & 0.48 & 0.67 & 0.68 & 0.86 & 0.66 & 0.68 & 1.02 \\
\hline
\end{tabular}


Table 1. CFA analysis of the refined survey instrument

\begin{tabular}{|c|c|c|c|c|c|c|c|c|c|c|}
\hline \multirow{2}{*}{ Construct } & \multirow{2}{*}{$\begin{array}{c}\text { Number of } \\
\text { items }\end{array}$} & \multirow{2}{*}{$\begin{array}{l}\text { Cronbach's } \\
\text { alpha }\end{array}$} & \multirow{2}{*}{$\begin{array}{l}\text { Construct } \\
\text { reliability }\end{array}$} & \multirow{2}{*}{ AVE } & \multicolumn{6}{|c|}{ Squared factor correlations } \\
\hline & & & & & SCP & $\mathrm{RR}$ & PR & IA & MT & SBP \\
\hline SCP & 4 & 0.86 & 0.86 & 0.61 & 1.00 & & & & & \\
\hline $\mathrm{RR}$ & 5 & 0.83 & 0.83 & 0.50 & 0.00 & 1.00 & & & & \\
\hline PR & 3 & 0.74 & 0.75 & 0.50 & 0.02 & 0.35 & 1.00 & & & \\
\hline $\mathrm{IA}$ & 3 & 0.79 & 0.79 & 0.56 & 0.03 & 0.34 & 0.12 & 1.00 & & \\
\hline MT & 2 & 0.83 & 0.83 & 0.71 & 0.07 & 0.35 & 0.12 & $0.69 *$ & 1.00 & \\
\hline SBP & 4 & 0.87 & 0.88 & 0.65 & 0.01 & 0.28 & 0.16 & $0.67^{*}$ & $0.74^{*}$ & 1.00 \\
\hline
\end{tabular}

Goodness of fit: $\chi^{2}=225.49, d f=174, P<0.05, \chi^{2} / d f=1.30, I F I=0.99, C F I=0.99, R M S E A=0.04$

Notes: Sample size $=156 . R R=$ Relational risk, $P R=$ Performance risk, $I A=$ Internal awareness, $M T=$ Monitoring, $S B P=$ Sharing best practice.

Construct reliability: $\rho_{c}=(\Sigma \lambda) 2 /[(\Sigma \lambda) 2+\Sigma \operatorname{var}(\delta)], A V E=\Sigma \lambda 2 /[\Sigma \lambda 2+\Sigma \operatorname{var}(\delta)]$.

* Squared factor loadings greater than corresponding AVEs.

$A V E=$ average variance extracted. 


\begin{tabular}{|c|c|c|c|c|c|}
\hline \multirow[t]{2}{*}{ Exogenous (controlled) variables } & \multicolumn{5}{|c|}{ Endogenous variables } \\
\hline & Internal awareness & Monitoring & Sharing best practice & Relational risk & Performance risk \\
\hline $\mathrm{H} 1(\mathrm{a}, \mathrm{b}, \mathrm{c})$ : Supply chain partnership (SCP) & $0.23 * *(2.33)$ & $0.30^{* *}(3.02)$ & $0.17 *(1.86)$ & - & - \\
\hline $\mathrm{H} 2 \mathrm{a}$ and $\mathrm{H} 2 \mathrm{~b}$ : Internal awareness $(\mathrm{IA})$ & - & - & - & $0.29 * *(2.90)$ & $0.17(1.68)$ \\
\hline $\mathrm{H} 3 \mathrm{a}$ and $\mathrm{H} 3 \mathrm{~b}$ : Monitoring (MT) & - & - & - & $0.32 * *(3.18)$ & $0.07(0.72)$ \\
\hline $\mathrm{H} 4 \mathrm{a}$ and $\mathrm{H} 4 \mathrm{~b}$ : Sharing best practice (SBP) & - & - & - & $0.18 * *(2.02)$ & $0.25 * * *(2.57)$ \\
\hline
\end{tabular}

Goodness of fit: $\chi^{2}=470.90, d f=180, P<0.005, \chi^{2} / d f=2.62, I F I=0.91, C F I=0.91, R M S E A=0.10$

Notes: Sample size $=156$. *Borderline significant path estimate; ${ }^{* *}$ Significant path estimate.

Table 3. Model M1.1 with direct path between SCP and relational risk (RR) - results of SEM: standardised path coefficients (t-value)

Exogenous (controlled) variables

$H 1(a, b, c)$ : Supply chain partnership (SCP)

$\mathrm{H} 2 \mathrm{a}$ and $\mathrm{H} 2 \mathrm{~b}$ : Internal awareness (IA)

$\mathrm{H} 3 \mathrm{a}$ and $\mathrm{H} 3 \mathrm{~b}$ : Monitoring (MT)

$\mathrm{H} 4 \mathrm{a}$ and $\mathrm{H} 4 \mathrm{~b}$ : Sharing best practice (SBP)

Mediating effect

H5a: SCP

Goodness of fit: $\chi^{2}=470.82, d f=179, P<0.005, \chi^{2} / d f=2.63, I F I=0.91, C F I=0.91, R M S E A=0.10$

Notes: Sample size $=156 .{ }^{*}$ Borderline significant path estimate; $* *$ Significant path estimate.

\begin{tabular}{ccccc}
\hline \multicolumn{5}{c}{ Endogenous variables } \\
\hline Internal awareness & Monitoring & Sharing best practice & Relational risk & Performance risk \\
$0.24^{* *}(2.44)$ & $0.31^{* *}(3.14)$ & $0.17^{*}(1.91)$ & - & - \\
- & - & - & $0.32^{* *}(3.08)$ & $0.18(1.73)$ \\
- & - & - & $0.40^{* *}(3.68)$ & $0.09(0.92)$ \\
- & - & & $0.13(1.53)$ & $0.23^{* *}(2.39)$
\end{tabular}

Endogenous variables

ing best practice

$0.18^{* *}(2.02)$ 
Table 4. Model M1.2 with direct path between SCP and performance risk (PR) - results of SEM: standardised path coefficients (t-value)

\begin{tabular}{|c|c|c|c|c|c|}
\hline \multirow[t]{2}{*}{ Exogenous (controlled) variables } & \multicolumn{5}{|c|}{ Endogenous variables } \\
\hline & Internal awareness & Monitoring & Sharing best practice & Relational risk & Performance risk \\
\hline $\mathrm{H} 1(\mathrm{a}, \mathrm{b}, \mathrm{c})$ : Supply chain partnership (SCP) & $0.22 * *(2.30)$ & $0.30 * *(2.99)$ & $0.17 *(1.84)$ & - & - \\
\hline $\mathrm{H} 2 \mathrm{a}$ and $\mathrm{H} 2 \mathrm{~b}$ : Internal awareness (IA) & - & - & - & $0.29 * *(2.97)$ & $0.17(1.62)$ \\
\hline $\mathrm{H} 3 \mathrm{a}$ and $\mathrm{H} 3 \mathrm{~b}$ : Monitoring (MT) & - & - & - & $0.30 * *(3.03)$ & $0.01(0.12)$ \\
\hline $\mathrm{H} 4 \mathrm{a}$ and $\mathrm{H} 4 \mathrm{~b}$ : Sharing best practice (SBP) & - & - & - & $0.19 * *(2.12)$ & $0.28 * *(2.82)$ \\
\hline Mediating effect & & & & & $0.08(0.71)$ \\
\hline
\end{tabular}

Goodness of fit: $\chi^{2}=471.17, d f=179, P<0.05, \chi^{2} / d f=2.63,|F|=0.91, C F I=0.91, R M S E A=0.10$

Notes: Sample size $=156$. ${ }^{*}$ Borderline significant path estimate; ${ }^{* *}$ Significant path estimate. 


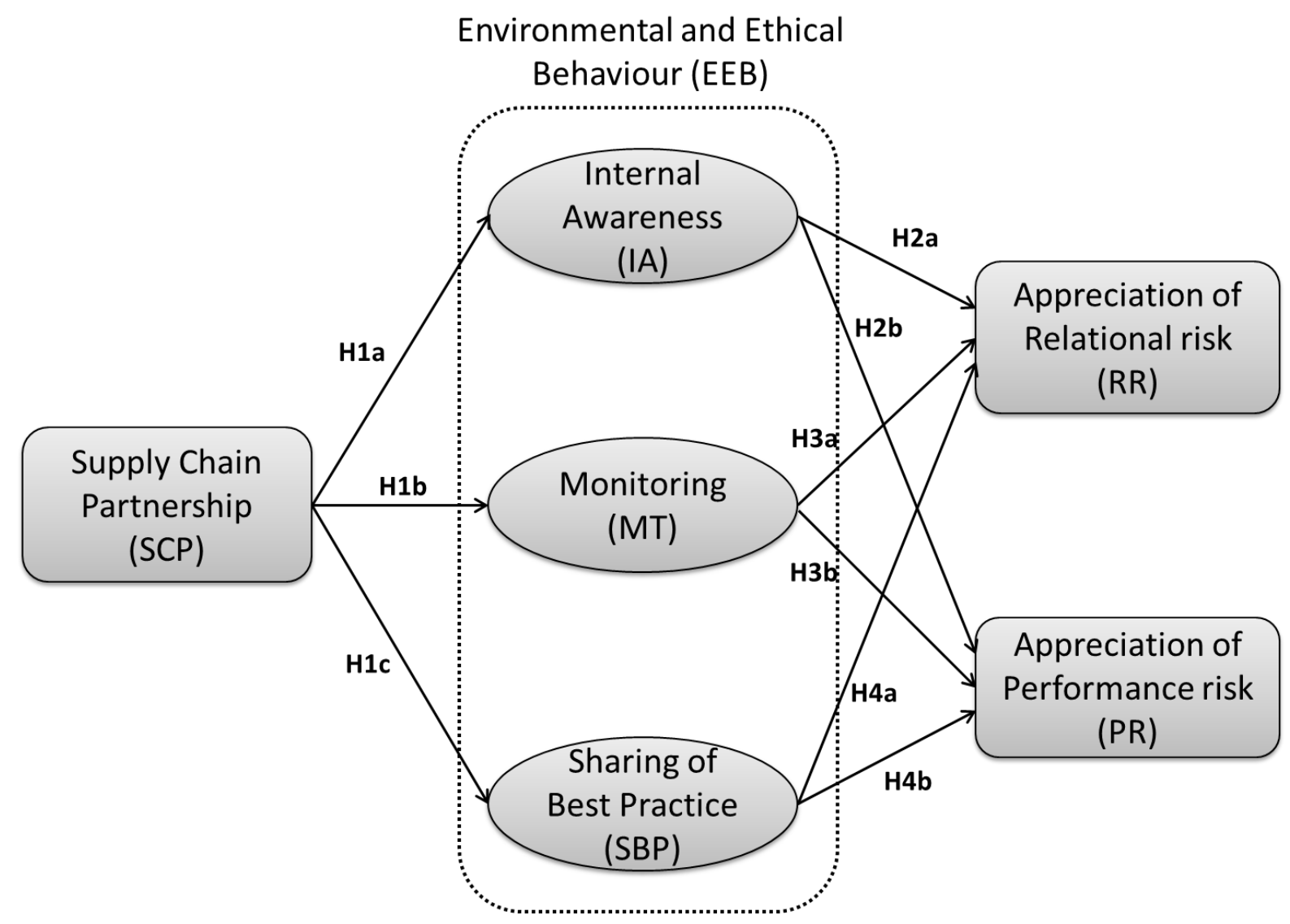

Figure 1. Research model 